\title{
Special issue on invasive pests of forests and urban trees: pathways, early detection, and management
}

\author{
Jon Sweeney ${ }^{1}$ (1) Davide Rassati ${ }^{2} \cdot$ Nicolas Meurisse $^{3} \cdot$ Brett Hurley $^{4} \cdot$ Jian Duan $^{5} \cdot$ Christian Stauffer $^{6}$. \\ Andrea Battisti $^{2}$
}

Received: 6 December 2018 / Accepted: 10 December 2018 / Published online: 4 January 2019

(c) Springer-Verlag GmbH Germany, part of Springer Nature 2019

Invasive insects cause significant economic and ecological damage to urban and natural forests worldwide (Aukema et al. 2011; Bradshaw et al. 2016). Species such as the emerald ash borer and the red bay ambrosia beetle (vector of laurel wilt disease), for example, threaten to extirpate North American ash (Herms and McCullough 2014) and species in the Lauraceae family (Kendra et al. 2013), respectively, with cascading negative impacts on ecosystem function and services (Gandhi and Herms 2009; Riggins et al. 2018). Adopted preventive measures have reduced but not eliminated the international movement of live insects (Haack et al. 2014; Ormsby and Brenton-Rule 2017), and the rate of new exotic insect introductions shows no or little sign of slowing in the face of expanding global trade (Brockerhoff and Liebhold 2017; Seebens et al. 2017). Therefore, the need

Communicated by Michael Traugott.

Special issue on "Invasive insect pests of forests and urban trees: pathways, early detection and management."

Jon Sweeney

jon.sweeney@canada.ca

1 Canadian Forest Service - Atlantic Forestry Centre, Natural Resources Canada, 1350 Regent St, Fredericton, NB, Canada

2 Department of Agronomy, Food, Natural Resources, Animals and Environment (DAFNAE), University of Padova, Viale dell' Università, 16, 35020 Legnaro, PD, Italy

3 Scion (New Zealand Forest Research Institute), 49 Sala Street, Private Bag 3020, Rotorua 3046, New Zealand

4 Department of Zoology and Entomology, Forestry and Agricultural Biotechnology Institute (FABI), University of Pretoria, Pretoria 0002, South Africa

5 Beneficial Insects Introduction Research Unit, United States Department of Agriculture, Agricultural Research Service, 501 South Chapel Street, Newark, DE, USA

6 Department of Forest and Soil Sciences, University of Natural Resources and Life Sciences, Vienna, Austria for improved tools, strategies, and policies for prevention, early detection, and management of invasive forest insects is critical.

This special issue on pathways, early detection, and management of invasive pests of forests and urban trees was spawned in a symposium entitled "Invasive species surveillance: new methods and tools for survey and early detection," held at the International Union of Forestry Research Organizations (IUFRO) 125th Anniversary Congress in Freiburg, Germany, September 19-22, 2017. The issue contains eleven reviews on topics ranging from the use of sentinel plantings to predict the impact of an exotic species before potential introduction (Eschen et al. 2018) and the pathways by which forest insects are commonly transported internationally (Meurisse et al. 2018), to current methods of biosurveillance (Poland and Rassati 2018) and how these could be enhanced using genomics (Bilodeau et al. 2018; Roe et al. 2018), to historical attempts to eradicate or contain invasive forest insects and the factors associated with their failure or success (Liebhold and Kean 2018). Several reviews focus on the management of particular invasive insect pests of urban and forest tree species (e.g., Avtzis et al. 2018; Corley et al. 2018; Hérard and Maspero 2018; Kirichenko et al. 2018; Milosavljević et al. 2018). The special issue also contains sixteen original papers and a rapid communication that advance our knowledge of phytosanitary treatments (Pawson et al. 2018), ways invasive species spread in new habitats (Javal et al. 2017; Lesieur et al. 2018; Lo et al. 2018), and improved tools and strategies for their early detection (e.g., Fan et al. 2018; Rassati et al. 2018) and management (e.g., Ferracini et al. 2018).

We thank the editors of Journal of Pest Science for agreeing to publish this special issue and all of the authors for their contributions, and we hope that the information and discoveries in this issue will be used to improve our 
capacity to manage invasive pests of urban and forest trees more effectively.

\section{Compliance with ethical standards}

Conflict of interest Authors Jon Sweeney, Davide Rassati, Nicolas Meurisse, Brett Hurley, Jian Duan, Christian Stauffer, and Andrea Battisti declare that they have no conflict of interest..

Ethical approval All applicable international, national, and/or institutional guidelines for the care and use of animals were followed.

\section{References}

Aukema JE, Leung B, Kovacs K, Chivers C, Britton KO et al (2011) Economic impact of non-native forest insects in the continental United States. PLoS ONE 6(9):e24587. https://doi.org/10.1371/ journal.pone. 0024587

Avtzis DN, Melika G, Matošević D, Coyle DR (2018) The Asian chestnut gall wasp Dryocosmus kuriphilus: a global invader and a successful case of classical biological control. J Pest Sci. https://doi. org/10.1007/s10340-018-1046-1 (this issue)

Bilodeau P, Roe A, Bilodeau G, Blackburn G, Cui M et al (2018) Biosurveillance of forest insects: part II-adoption of genomic tools by end user communities and barriers to integration. J Pest Sci. https ://doi.org/10.1007/s10340-018-1001-1 (this issue)

Bradshaw CA, Leroy B, Bellard C, Roiz D, Albert C et al (2016) Massive yet grossly underestimated global costs of invasive insects. Nat Commun 7:12986. https://doi.org/10.1038/ncomms 12986

Brockerhoff EG, Liebhold AM (2017) Ecology of forest insect invasions. Biol Invasions 19:1-19

Corley JC, Lantschner MV, Martinez AS, Fischbein D, Villacide JM (2018) management of Sirex noctilio populations in exotic pine plantations: critical issues explaining invasion success and damage levels in South America. J Pest Sci. https://doi.org/10.1007/ s10340-018-1060-3 (this issue)

Eschen R, O'Hanlon R, Santini A, Vannini A, Roques A et al (2018) Safeguarding global plant health: the rise of sentinels. J Pest Sci. https://doi.org/10.1007/s10340-018-1041-6 (this issue)

Fan J, Denux O, Courtin C, Bernard C, Javal M et al (2018) Multicomponent blends for trapping native and exotic longhorn beetles at potential points-of-entry and in forests. J Pest Sci. https://doi. org/10.1007/s10340-018-0997-6 (this issue)

Ferracini C, Ferrari E, Pontini M, Saladini MO, Alma A (2018) Effectiveness of Torymus sinensis: a successful long-term control of the Asian chestnut gall wasp in Italy. J Pest Sci. https://doi. org/10.1007/s10340-018-0989-6 (this issue)

Gandhi KJK, Herms DA (2009) North American arthropods at risk due to widespread Fraxinus mortality caused by the alien emerald ash borer. Biol Invasions 12:1839-1846

Haack RA, Britton KO, Brockerhoff EG, Cavey JF, Garrett E et al (2014) Effectiveness of the international phytosanitary standard ISPM No. 15 on reducing wood borer infestation rates in wood packaging material entering the United States. PLoS ONE 9(5):e96611. https://doi.org/10.1371/journal.pone.0096611

Hérard F, Maspero M (2018) History of discoveries and management of the citrus longhorned beetle, Anoplophora chinensis, in Europe. J Pest Sci. https://doi.org/10.1007/s10340-018-1014-9 (this issue)
Herms DA, McCullough DG (2014) Emerald ash borer invasion of North America: history, biology, ecology, impacts, and management. Annu Rev Entomol 59:13-30

Javal M, Roques A, Haran J, Hérard F, Keena M, Roux G (2017) Complex invasion history of the Asian long-horned beetle: fifteen years after first detection in Europe. J Pest Sci. https://doi.org/10.1007/ s10340-017-0917-1 (this issue)

Kendra PE, Montgomery WS, Niogret J, Epsky ND (2013) An uncertain future for American Lauraceae: a lethal threat from redbay ambrosia beetle and laurel wilt diseases (a review). Am J Plant Sci 4:727-738

Kirichenko N, Augustin S, Kenis M (2018) Invasive leafminers on woody plants: a global review of pathways, impact, and management. J Pest Sci. https://doi.org/10.1007/s10340-018-1009-6 (this issue)

Lesieur V, Lombaert E, Guillemand T, Courtial B, Strong W, Roques A, Auger-Rozenberg M-A (2018) The rapid spread of Leptoglossus occidentalis in Europe: a bridgehead invasion. J Pest Sci. https ://doi.org/10.1007/s10340-018-0993-x (this issue)

Liebhold AM, Kean JM (2018) Eradication and containment of nonnative forest insects: successes and failures. J Pest Sci. https://doi. org/10.1007/s10340-018-1056-z (this issue)

Lo N, Montagu A, Noack A, Nahrung H, Wei H et al (2018) Population genetics of the Australian eucalypt pest Thaumastocoris peregrinus: evidence for a recent invasion of Sydney. J Pest Sci. https:// doi.org/10.1007/s10340-018-0995-8 (this issue)

Meurisse N, Rassati D, Hurley BP, Brockerhoff EG, Haack RA (2018) Common pathways by which non-native forest insects move internationally and domestically. J Pest Sci. https://doi.org/10.1007/ s10340-018-0990-0 (this issue)

Milosavljević I, El-Shafie HA, Faleiro JR, Hoddle CD, Lewis M, Hoddle MS (2018) Palmageddon: the wasting of ornamental palms by invasive palm weevils, Rhynchophorus spp. J Pest Sci. https://doi. org/10.1007/s10340-018-1044-3 (this issue)

Ormsby M, Brenton-Rule E (2017) A review of global instruments to combat invasive alien species in forestry. Biol Invasions 19:3355-3364

Pawson SM, Bader MK-F, Hefferman WJB, Kerr JL, O'Conner BO (2018) Quantifying the thermal tolerance of wood borers and bark beetles for the development of Joule heating as a phytosanitary treatment of pine logs. J Pest Sci. https://doi.org/10.1007/s1034 $0-018-1015-8$ (this issue)

Poland TM, Rassati D (2018) Improved biosecurity surveillance of non-native forest insects: a review of current methods. J Pest Sci. https://doi.org/10.1007/s10340-018-1004-y (this issue)

Rassati D, Marini L, Marchioro M, Rapuzzi P, Magnani G et al (2018) Developing trapping protocols for wood boring beetles associated with broadleaf trees. J Pest Sci. https://doi.org/10.1007/s1034 0-018-0984-y (this issue)

Riggins JJ, Chupp AD, Formby JP, Dearing NA, Bares HM, Brown RL, Oten KF (2018) Impacts of laurel wilt disease on arthropod herbivores of North American Lauraceae. Biol Invasions. https:// doi.org/10.1007/s10530-018-1838-5

Roe AD, Torson AS, Bilodeau G, Bilodeau P, Blackburn GS et al (2018) Biosurveillance of forest insects: part I-integration and application of genomic tools to the surveillance of non-native forest insects. J Pest Sci. https://doi.org/10.1007/s10340-018-1027-4 (this issue)

Seebens H, Blackburn TM, Dyer EE, Genovesi P, Hulme PE et al (2017) No saturation in the accumulation of alien species worldwide. Nat Commun 8:14435. https://doi.org/10.1038/ncomm s14435 